made by heating refractory materials by passing an electric current through them. The electric arc between carbon electrodes was one of the first satisfactory sources. Since the temperature of the carbon may reach $5000^{\circ} \mathrm{C}$., the light is very similar in quality to that of the sun. But the efficiency is not high and the operation is too complicated for most purposes. The carbon filament incandescent lamp was a poor substitute, as in a high vacuum carbon volatilizes rather easily, with the result that the temperature is only about $1800^{\circ} \mathrm{C}$. The tungsten filament was a great improvement, the working temperature of the filament rising to $2400^{\circ} \mathrm{C}$. Wo can in this case use an inert gas like argon or nitrogen, thus making a lamp twice as efficient as the carbon filament lamp. A further improvement can bo introduced by coiling the filament on itself.

A still more efficient lamp can be made by intro. lucing $\Omega$ now method, namely, the phenomena accompanying electric discharge in rarefied gases. If a dischargo tube be evacuated, it needs a very high potential difference applied across its terminals to produco a flash. By reducing the pressuro to about $1 / 1000$ of an atmosphere a much smaller voltage suffices to produce a steady discharge which fills the tube with light. A variety of colours can bo obtained by using various gases instead of air. By constructing the interior of the lamp of fused silica and fixing a suit. able conducting cathode, the pressure may bo increased up to 100 atmospheres with a corresponding increase in luminous output.

The latest type of discharge lamp uses low-pressure discharge, in which the intensity of the ultra-violet radiation is a maximum, and a fluorescent substance which emits visible light under the action of ultra. violet light is put inside the tube. A series of such lamps can bo devised with colours which when suitably blended give white light. To obtain white light from a single lamp, a mixture of powders is fused on to the inside of the discharge tube. The new discharge lamps have brought us very close to the perfectly efficient source.

\section{SCIENCE AND THE COMMUNITY}

A PUBLIC lecture "Science and the Community" given by Prof. Alex Findlay on September 12, 1938 , at the invitation of the Council of the Univer. sity of $\mathrm{C}$ go, Dunedin, has been published by the Now Zeaiand Council for Educational Research ("Studies in Education", No. 4. London : Oxford University Press). . Referring to the achievements of applied science in ministering to the health and material comfort of the people and to industrial efficiency and development, Prof. Findlay points out that science is knowledgo and that knowledge can bo gained only by persistent inquiry or research, and he urges the importance for the relfare of the country that not merely a fow but all the people should become research-minded and recognize with conviction that research is the best insurance of the future. Welcoming the greater attention being paid to the human factor in industry and to the consequences of the impact of science on our social organization, he considers that in proclaiming the great achievements of science we should beware of losing sight of the idealism of science. For the community as a whole, it is not the aequisition of a knowledge of scientific facts that is of chief importance but the inculcation of the spirit of science.

The first great aim of science is the seeking out of truth, and scientific truth is one of the great human values essential for a complete life. Science is, however, not merely an amassing of facts; its spirit is also to bo found in the great hypotheses and theories of science, and the cultivation of the spirit of science makes an æsthetic as well as an intellectual appeal, strengthening and perfecting the fulfilment of that other essential factor in a complete human nature, the desire for beauty. Cultivation of the spirit of scienco is also necessary for the body politic. To cure or ameliorate the evils which flow from the weaknessos to which all democratic government is subject, we must work for a greater knowledge and honesty of purpose, a higher cultural level in the community.

Urging that science is an important factor in the moral and social development of the people, Prof. Findlay stresses the importance of ensuring that the minds of all university students should bo opened to scientific truth as revealed in the physical and biological sciences and to recognize the importance of method and facts, as well as ideas. For this ho doos not consider that laboratory work is essential. As regards the place of men of science in the State and in the general life of the community, he suggests that our present dangers are due to neglect of the ethical rather than of tho scientific values. While he would not support any plea for a special place for the man of science as such in the councils of govern. ment, he urges the duty of men of science to cultivate a rich humanity and to educate their minds to take a wide viow and form $a$ balanced judgment, to enablo them to take a much fuller sharo in the common duties of citizenship, placing more unreservedly at the disposal of their fellow citizens that contribution of special knowledge and outlook which their training and studies enable them to make. By cultivating the human values not only of science but also of art and religion, and building into their personalities the qualities of truth, beauty and goodness, scientific men can do much to form a more enlightened public opinion and help in the solution of the educational, social, economic and other problems which face the community. They should strive not merely to bring about a planned order of society with a purely materialistic outlook, but also an order in which individual human nature can find its full expression through the cultivation of truth, beauty and goodness.

\section{UNIVERSITY EVENTS}

ST. ANDrews.- - In view of the cancellation, owing to national emergency, of the graduation ceremonial appointed to be held by the University of St. Andrews on the occasion of the visit to Dundee of the British Association, the Senatus Academicus have conferred the honorary degree of LL.D. in absentia on the following, who were to be recipients of the degree upon that occasion: Prof. F. T. Brooks, Dr. C. G. Darwin, Sir Albert Seward, Prof. R. V. Southwell, Lord Stamp, Sir Aurel Stein.

Dr. Cyril Dodd, of Durham, has been appointed to the lectureship in natural philosophy in the United College, St. Andrews, which fell vacant on the appointment of Dr. F. L. Arnot to a post in Australia. 